SNPs and to measure the distribution of IL-10 SNPs in RA versus controls.

Methods DNA of high and low IL10 producers were sequenced. Subsequently, the association between LPS-induced IL-10 production and previously described panel was analysed.

Results The following SNPs were identified:

-3575 A to $G,-2849$ A to $G,-2763$ A to $C$ and -1330 A to G. Previously we have identified 4 ancestral IL-10 haplotypes. The current SNP?s on: IL10.1 R3-AAAA-(IL10G)-GCC, IL10.2 R2-TGCG-(IL10G)-ACC，IL10.3 R2-AGAA-(IL10G)-GCC, and IL10.4 R2-TGCC-(IL10G)-ATA. To investigate whether these SNP?s were functional we analysed the LPS-induced IL-10 production of 161 healthy donors with a specific genotype: -3575: AA (n = 38) $1896 \mathrm{ng} / \mathrm{ml}$, AT $(\mathrm{n}=76) 3232 \mathrm{ng} / \mathrm{ml}$, TT (n = 47) $3195 \mathrm{ng} / \mathrm{ml}$. -2849: AA $(\mathrm{n}=21) 2115 \mathrm{ng} / \mathrm{ml}, \mathrm{AG}(\mathrm{n}=75)$ $2950 \mathrm{ng} / \mathrm{ml}, \mathrm{GG}(\mathrm{n}=65) 3111 \mathrm{ng} / \mathrm{ml}$ (MW-test both $\mathrm{p}<0.05)$. Next, the analysis was repeated in a different group of donors: 135 partners of patients with SLE/MS: -3575: AA $(\mathrm{n}=29)$ $4190 \mathrm{ng} / \mathrm{ml}$, AT $(\mathrm{n}=71) 4521 \mathrm{ng} / \mathrm{ml}$, TT $(\mathrm{n}=35) 4401 \mathrm{ng} / \mathrm{ml}$ (MW-test $\mathrm{P}=0.6)$. -2849: AA $(\mathrm{n}=26) 3845 \mathrm{ng} / \mathrm{ml}, \mathrm{AG}(\mathrm{n}=$ 41) $4577 \mathrm{ng} / \mathrm{ml}, \mathrm{GG}(\mathrm{n}=68) 4543 \mathrm{ng} / \mathrm{ml}(\mathrm{MW}$ ?test $\mathrm{P}=0.04$, for $G$ carrier versus non $G$ : $P=0.02$ ). Next, the distribution of -2849 SNP was compared in RA patients compared to controls. Control-Panels were 1) partners of MS-SLE patients and 2) organ donors. RA-patients were: 1) incident RA cases, 2) outpatient consecutive RA and 3) RA patients from our early arthritis cohort. Control 1) AA 27, AG 42, GG 71; 2) AA 16, AG 64, GG 88; RA patients 1) AA 3, AG 38, GG 51; 2) AA 24, AG 141, GG 152; 3) AA 16, AG 74, GG 91. Total chi-square: P = 0.0014 .

Conclusion We have previously found that the allele IL-10R3 microsatellite was less frequent in three ethnic groups of RA patients (Afro-americans $\mathrm{p}<0.01$, English $\mathrm{p}<0.008$ and Scottish $\mathrm{p}<0.02)$. The SNP that defines the haplotype on which R3 is located is also less prevalent in three groups of dutch RA compared to two groups of dutch controls. These data suggest that a high innate IL-10 production is a risk factor for RA. This may be due to the B-cell stimulating properties of IL-10.

\section{THU0027 EFFECTS OF LEFLUNOMIDE ON CYTOKINE PRODUCTION IN CULTURED RHEUMATOID SYNOVIAL CELLS}

P Vergne, B Liagre, P Bertin, C Bonnet, M Rigaud, UL Beneytout. Department of Rheumatology, University of Medecine, Limoges, France

\subsection{6/annrheumdis-2001.824}

Background Leflunomide (A 771726) has been shown recently to be effective in rheumatoid arthritis (RA). It inhibits cell proliferation in activated lymphocytes. Its faster onset of action could be due to both antiinflammatory and immunoregulatory properties.

Objectives The present study evaluated the effects of the drug on cytokine production in cultured human rheumatoid synovial cells.

Methods Adherent synovial cells were obtained by collagenase digestion of synovium, isolated from RA patients undergoing surgery. Between passages 4 and 6 , cultured synovial cells were incubated with 6 different concentrations of leflunomide $(10,20,40,60,80$ and $100 \mu \mathrm{M})$ and dexamethasone for $24 \mathrm{~h}$. Lipopolysaccharides (LPS) were or were not added for the last $6 \mathrm{~h}$ of incubation. Supernatants were assayed for IL-1 receptor antagonist (IL-1 RA), soluble type I receptor of tumour necrosis factor (sTNF RI) and interleukin-6 (IL-6) productions by ELISA. Statistical analysis of differences was carried out by analysis of variance (ANOVA).

Results IL-1 RA and IL-6 production of LPS-stimulated synovial cells were respectively 2.4 - and 1.7-fold higher than that of unstimulated cells. LPS did not enhance the production of sTNF RI. Leflunomide increased significantly $(\mathrm{p}<0,001)$ the production of IL-1 RA in a dose dependent manner with a plateau effect beyond $80 \mu \mathrm{M}$. Leflunomide decreased significantly $(\mathrm{p}<$ $0,001)$ the IL-6 production by 70 to $75 \%$ in a dose dependent manner. On the other hand, leflunomide did not have a significant effect on sTNF RI production. Dexamethasone decreased all the cytokine productions.

Conclusion Leflunomide could have an immunomodulatory action in the cytokine network involved in the pathogenesis of RA with a decrease production of the proinflammatory cytokine IL-6 and increase synthesis of the antiinflammatory cytokine IL1 RA.

This work has been supported by Aventis Pharma laboratory.

\section{THU0028 DIFFERENT VARIANTS OF TNF-ALPHA MRNA TRANSCRIPTS ARE EXPRESSED IN RATS WITH COLLAGEN-INDUCED ARTHRITIS}

${ }^{1}$ MF Seidel ${ }^{*},{ }^{2} \mathrm{MP}$ Junier, H Vetter ${ }^{3 *}$. ${ }^{1}$ Experimental Rheumatology, Rheumaklinik, Bad Bellingen, Germany; ${ }^{2}$ Neuroplasticite Et Therapeutique, INSERM Unite 421, Creteil Cedex, France; ${ }^{3}$ Medizinische Poliklinik, Universität Bonn, Bonn, Germany

\subsection{6/annrheumdis-2001.825}

Background Tumour necrosis factor alpha (TNF-a) is found in both, autoimmune and normal conditions and may therefore not mediate inflammation by overexpression alone. Upregulation of polymorph TNF-a peptides caused by single base pair (bp) exchanges in mRNA transcripts might modify inflammatory events in arthritis.

Objectives We wished to examine variants of TNF-a transcripts expressed in collagen-induced arthritis (CIA) as a classical model of autoimmune diseases.

Methods Severe osteodestructive CIA was induced in male Dark Agouti rats, the nature of arthritis was confirmed by radiology. Total articular RNA from diseased animals was used for cDNA synthesis. PCR was performed for the $705 \mathrm{bp}$ TNF-a propeptide and the amplified bands were cloned in E. coli. Two clones were sequenced and the results compared to the NIH gene bank. To confirm polymorph expressions ribonuclease protection assays (RPA) were performed with RNA from normal spleen tissue and joints from healthy and arthritic animals.

Results Radiology showed severe osteodestruction in CIA animals. Two clones with a complete open reading frame for the 705 bp TNF-a propeptide transcript were obtained by RT-PCR. Single base pair mismatches were found at position 365 and 568 leading to amino acid exchanges of proline versus leucine and lysine versus glutamic acid, respectively. Based on the NIH database four previously published rat TNF-a sequences showed up to twelve single base pair mismatches. In RPA analyses we found protected bands at 705 bp size in all conditions. In addition, smaller bands indicated the presence of transcripts with several single base pair mismatches. Some fragments were not observed in healthy control joints.

Conclusion The two novel TNF-a transcripts described here are expressed in arthritic and control animals displaying a nonspecific polymorphism. The additional presence of smaller bands in the RPA suggest the coexpression of similar transcripts which 